accompanying gastroesophageal reflux or through the lining of the distal esophagus with acid-producing gastric mucosa. While in the first case an antireflux operation, for example fundoplication, must be carried out, in the second case the main purpose of surgery is to reduce acid production in the esophagus. Details of 42 patients with peptic stenosis are set out.

Key words: Endobrachyesophagus (Syndrome, Barrett’s) - Stenosis, peptic esophageal.

Zusammenfassung. Der Endobrachyoesophagus ist in aller Regel eine erworbene Zylinderepithelmetaplasie des distalen Oesophagus. Seine angeborene Variante ist sehr selten. Neben der malignen Entartung und dem Ulcus oesophagi ist die peptische Stenose die häufigste Komplikation. Sie entwikkelt sich einmal bei gleichzeitigem Vorliegen eines gastrooesophagealen Refluxes, zum anderen bei Auskleidung des distalen Oesophagus mit säurezernierender Magenschleimhaut. Während im 1.Fall eine Antirefluxoperation, z. B. in Form der Fundoplicatio, durchgeführt werden muß, steht die Reduzierung des Säurepotentials im Oesophagus im 2. Fall im Zentrum der chirurgischen Maßnahmen. Die eigenen Erfahrungen an insgesamt 42 peptischen Stenosen werden dargestellt.

Schliisselwörter: Endobrachyoesophagus (Barrett-Syndrom) - Peptische Oesophagusstenosen.

\title{
138. Perforierende Verletzung des Oesophagus
}

\author{
F. K. Lynen, T. Raguse und G. Schuster \\ Chirurgische Klinik der RWTH Aachen
}

\section{Esophageal Perforation}

Summary. Iatrogenic endoscopic perforation accounts for the majority of esophageal injuries, with a frequency of 0.1 percent and a mortality of 20-30 percent. Successful management and a favorable prognosis depend on early diagnosis. Esophagoscopy is paradoxically of great value in the diagnosis of small perforations, with a negative esophagogram. Prompt surgical management with closure of the defect and adequate drainage is mandatory, and this involves the lowest mortality. A conservative approach with only drainage of the defect is justified in longer-standing perforations and in patients whose general condition is poor.

Key words: Injury, esophageal - Perforation.

Zusammenfassung. Mit einer Frequenz von $0,1 \%$ bei einer Globalletalität von $20-30 \%$ ist die Oesophagusperforation eine seltene, aber lebensbedrohliche Komplikation, die in der Mehrzahl der Fälle Folge einer iatrogenen endoskopischen Läsion ist. Entscheidend für die Prognose und den Verlauf ist die Frühdiagnose. Bei kleinen, röntgenologisch nicht nachweisbaren Perforationen kann hierbei paradoxer Weise die Oesophagoskopie wertvolle diagnostische Hilfestellung geben. Therapie der Wahl ist bei der geringsten Letalität die frühzeitige chirurgische Intervention mit Übernähung und Drainage. Nur bei älteren Perforationen und bei schlechtem Allgemeinzustand scheint das primär konservative nur drainierende Vorgehen gerechtfertigt.

Schlüsselwörter: Oesophagus - Perforation. 